\title{
Possibility of Atmospheric Pressure Plasma Jet Application in Decontamination of Heat Sensitive Surfaces
}

\author{
Joanna Pawłat \\ Lublin University of Technology, \\ Nadbystrzycka St. 38A, 20-618 Lublin, Poland \\ * Corresponding author e-mail: askmik@hotmail.com
}

\begin{abstract}
Device working in ambient environment, which will generate plasma of parameters enabling treatment and sterilization of inanimate materials and living tissues was developed. Features of the proposed plasma jet are ability to work with various feed-gases in several gas flow, frequency and current- voltage regimes. LabVIEW virtual measurement sub-system for monitoring and measurement process was applied. Electrical characteristics of plasma reactor, temperature measurement results are presented, and achieved ozone concentrations are given. Key words: atmospheric pressure plasma jet, plasma for biodecontamination, APPJ properties
\end{abstract}

\section{INTRODUCTION}

Knowing that plasma and Advanced Oxidation Processes (AOPs) are very efficient towards variety of chemical and biological contaminants, many plasma sterilizing devices working in the ambient conditions are under investigation [1-22]. Pathogens can be easily inactivated by AOPs, particularly by ozone, hydrogen peroxide, $\mathrm{OH}$ radicals, $\mathrm{H}_{2} \mathrm{O}_{2}$, peroxynitrite, $\mathrm{UV}$ radiation, etc. Cells and spores inactivation mechanisms like direct destruction, volatization and etching of the cells, oxidative stress and nitrogen stress were extensively studied [23-35].

New branch of science: plasma medicine emerged in the last decade as an interdisciplinary field of research [36-44]. The ultimate goal of all above efforts is the development and proper evaluation procedure for the device generating tissue tolerable plasma (TTP) [45].

Temperature of plasma boundaries and of the surface undergoing treatment are the crucial factor for classifying the device as a tissue tolerable plasma generator. During the temperature measurement in aqueous targets, the group of Brisset proved that pathogens can be inactivated by low temperature plasma techniques but the thermal factor was not responsible for the lethal effect on the targeted bacteria [46].

The ultimate objective of this research was development of operator- and environmental- friendly low temperature atmospheric pressure plasma decontamination device, which should have operation cycle length at least the same as traditional set-ups, should be applicable in broad range of materials and surfaces without damaging them irreversibly. One of the perspective devices, fulfilling the requirements for TTP source is Atmospheric Pressure Plasma Jet (APPJ).

Usually powered changeable rod/needle/hollow electrode is there encapsulated in an insulated case. High flow of substrate gas mixtures consisting of inert carrier gas such as helium and another reactive gas (for instance $\mathrm{O}_{2}, \mathrm{H}_{2} \mathrm{O}$ or $\mathrm{CF}_{4}$ ) is used. Feed gas flows between closely spaced (coaxial or parallel plate arrangement) electrodes, which can be powered using various power sources resulting in different discharge types. Based on applied power source frequency APPJs can be divided into: low frequency $(\sim \mathrm{kHz})$, radio frequency $(\sim \mathrm{MHz})$ and -microwave frequency. The electric field produced between the electrodes causes the gas to breakdown into a plasma state. Homogeneous plasma can be generated in relatively large volume as an effect of discharges. While passing through the plasma, the substrate gas becomes excited, dissociated or ionized by energetic electron impact, producing short-lived reactive species, which are further propelled out of the source [47-50].
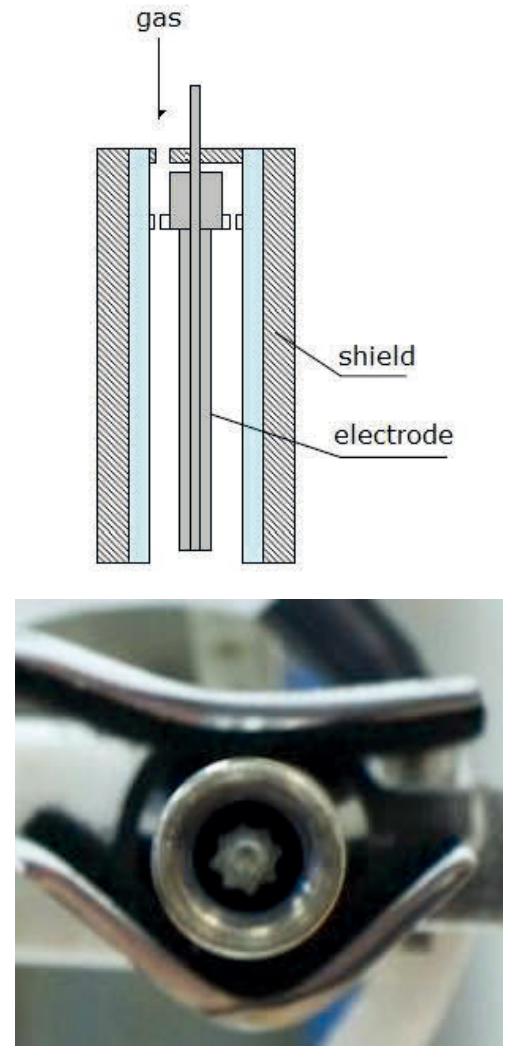

Fig. 1. Atmospheric pressure plasma jet. 


\section{EXPERIMENTAL SET-UP}

Proposed experimental set-up consisted of the following sub-systems:

- gas and liquid dosing sub-system,

- electrical discharge generating sub-system,

- control and data acquisition sub-system,

-chemical and biological analyzing sub-system.

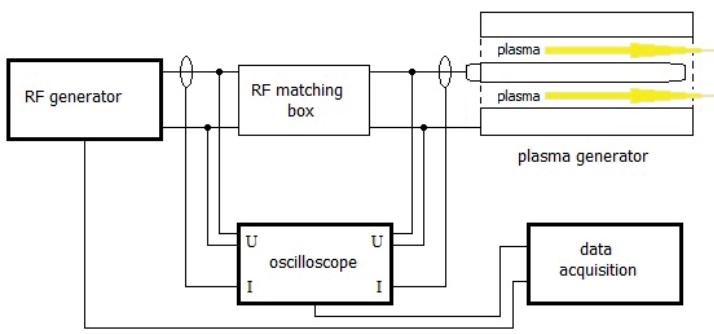

Fig. 2. Electrical supply of APPJ.

The main part of the device, which is presented in Fig. 1 , is RF-powered changeable rod electrode of tungsten or acid-proof stainless steel. 3 types of electrode shapes: flat surface, screw-type and turtle-type surface of diameters ranging from 4 to $6 \mathrm{~mm}$ were tested. The electrode was powered by a regulated RF supply (AG 1021 RF generator, T\&C Power Conversion) via impedance matching network. It was possible to power plasma reactor with frequencies from $10 \mathrm{kHz}$ to $20 \mathrm{MHz}$. The schema of electrical supply is depicted in Fig. 2.

LabVIEW virtual measurement sub-system has been developed. Application enables whole monitoring and measurement process through subsequent setting of electrical and gas-flow parameters (digital control of flow-meters), conditioning and amplification of electrical signals. Sub-system also automatically collects the data from Tektronix TDS2024B oscilloscope, voltage and current probes.

\section{EXPERIMENTAL RESULTS}

Current/voltage characteristics on the primary and secondary side are presented in Fig. 3. In dependence on the gas flow rate and the type of substrate gas, discharge plasma sizing from 10 to $20 \mathrm{~mm}$ in diameter and 5-15 $\mathrm{mm}$ in length was produced.

Discharge homogeneity changed in dependence on all tested factors: feed gas, gas flow rate, power supply parameters. The most homogenous plasma was generated in gas mixtures containing argon and helium and at gas flow rates exceeding $7.51 / \mathrm{min}$. From the discharge homogeneity point of view, the most beneficial are flat and turtle shape tungsten electrodes. From the RF generator point of view, the most stable operation, which resulted in the lowest ratio of reflected power was achieved at frequency range $12-15 \mathrm{MHz}$ (depending on the feed gas type).

It was possible to achieve temperatures below $40^{\circ} \mathrm{C}$ compromising applied power and gas flow-rate. The best results were obtained in air at high velocity and applied $\mathrm{RF}$ power of $80 \mathrm{~W}$. In this condition temperature was measured $2 \mathrm{~cm}$ from the physical outlet of the device and in the centre of the jet. Results of temperature measurement are depicted in Tab. 1.
A
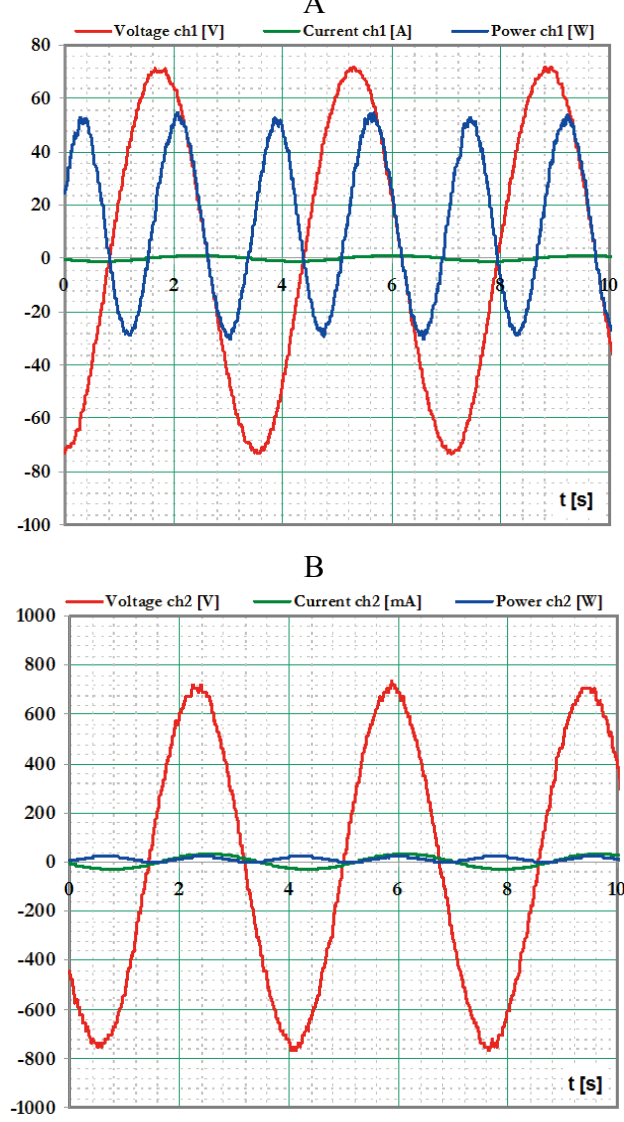

Fig. 3. Voltage/current characteristics (flow rate $9 \mathrm{1} / \mathrm{min}, 30 \% \mathrm{O}_{2} / 70 \% \mathrm{He}$ ) for primary side (A) and secondary side (B).

Tab. I. Plasma jet at different air gas flows, $\mathrm{P}=80 \mathrm{~W}, \mathrm{f}=12.98 \mathrm{MHz}, \mathrm{Q}$ - gas flow rate.

\begin{tabular}{|c|c|c|}
\hline $\begin{array}{c}\mathrm{Q}=0.2 \mathrm{~m}^{3} / \mathrm{h} ; \\
\mathrm{t}=170^{\circ} \mathrm{C}\end{array}$ & $\begin{array}{c}\mathrm{Q}=0.6 \mathrm{~m}^{3} / \mathrm{h} ; \\
\mathrm{t}=90^{\circ} \mathrm{C}\end{array}$ & $\begin{array}{c}\mathrm{Q}=1 \mathrm{~m}^{3} / \mathrm{h} ; \\
\mathrm{t}=35^{\circ} \mathrm{C}\end{array}$ \\
\hline & & \\
\hline & & \\
\hline & & \\
\hline
\end{tabular}

Results of temperature measurement in less favourable conditions ( $50 \mathrm{~W}$ of applied power), at different distances from the outlet of the jet are depicted in Fig. 4.

Ozone concentration was measured in dependence on the gas type, gas flow rate, power and the type of electrode via continuous gas sampling from sealed container of $0.5 \mathrm{dm}^{3}$ volume ( $22 \mathrm{~cm}$ length), where the plasma jet outlet was placed. Ozone concentration in the helium/air mixture in dependence on inner electrode diameter is presented in Fig. 5. 


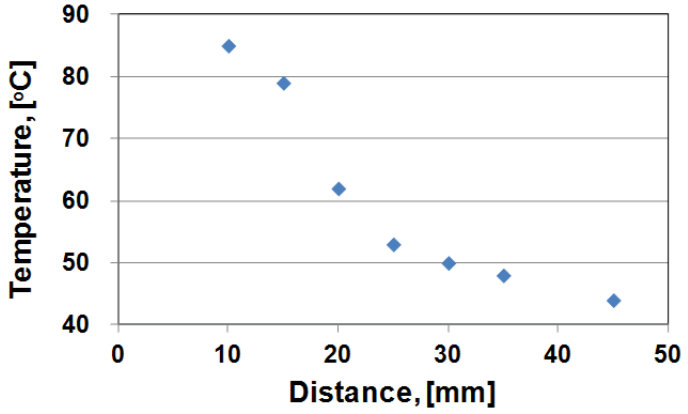

Fig.4. Dependence of temperature distribution on the distance from the outlet of the jet

(65\% oxygen $/ 35 \%$ helium, flow rate $24 \mathrm{l} / \mathrm{min}$, applied power $50 \mathrm{~W}$, frequency $14.23 \mathrm{MHz}$ )

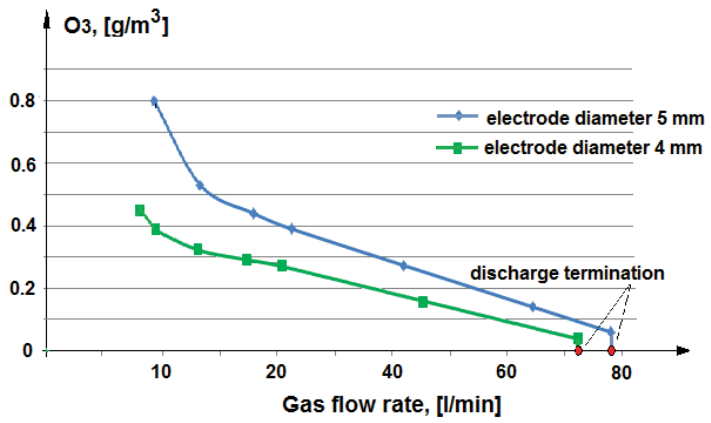

Fig. 5. Gaseous ozone concentrations. Electrodes diameters: $5 \mathrm{~mm}(\mathrm{f}=14.05 \mathrm{MHz})$ and $4 \mathrm{~mm}(\mathrm{f}=14.47 \mathrm{MHz}), \mathrm{P}=55 \mathrm{~W}, 33 \% \mathrm{O}_{2} / 67 \% \mathrm{He}$.

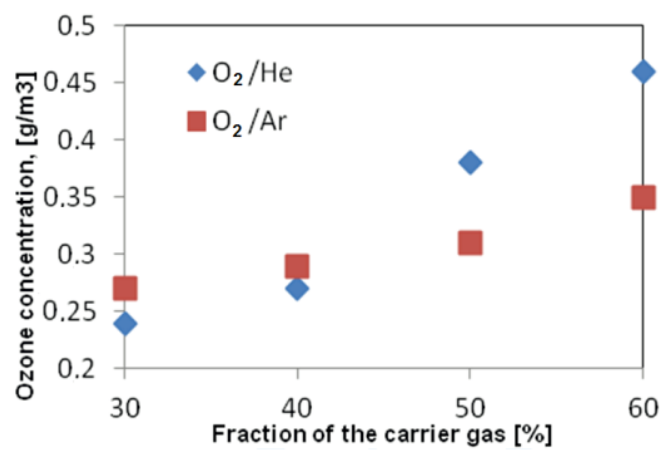

Fig. 6. Ozone concentration in dependence on the fraction of carrier gas: helium or argon.

Process gas: oxygen, total flowrate: $10 \mathrm{l} / \mathrm{min}, P=55 \mathrm{~W}$, $f=14.05 \mathrm{MHz}$.

Comparison of ozone concentration depending on the fraction of the argon and helium as a carrier gas added to oxygen, at $5 \mathrm{~mm}$ diameter, flat-surface electrode condition is presented in Fig. 6. Achieved ozone concentrations were low and ranged $0.82 \mathrm{~g} / \mathrm{m}^{3}$.

APPJ was used for the treatment of polyethylene terephthalate surfaces. Used treatment times ranged from 2 seconds to 2 minutes. Temporary increase of wettability after the plasma treatment was observed. Micrographs of PET surface after $15 \mathrm{~s} \mathrm{O}_{2} / \mathrm{He}$ plasma treatment taken by Raman microscopy are depicted in Fig. 7.
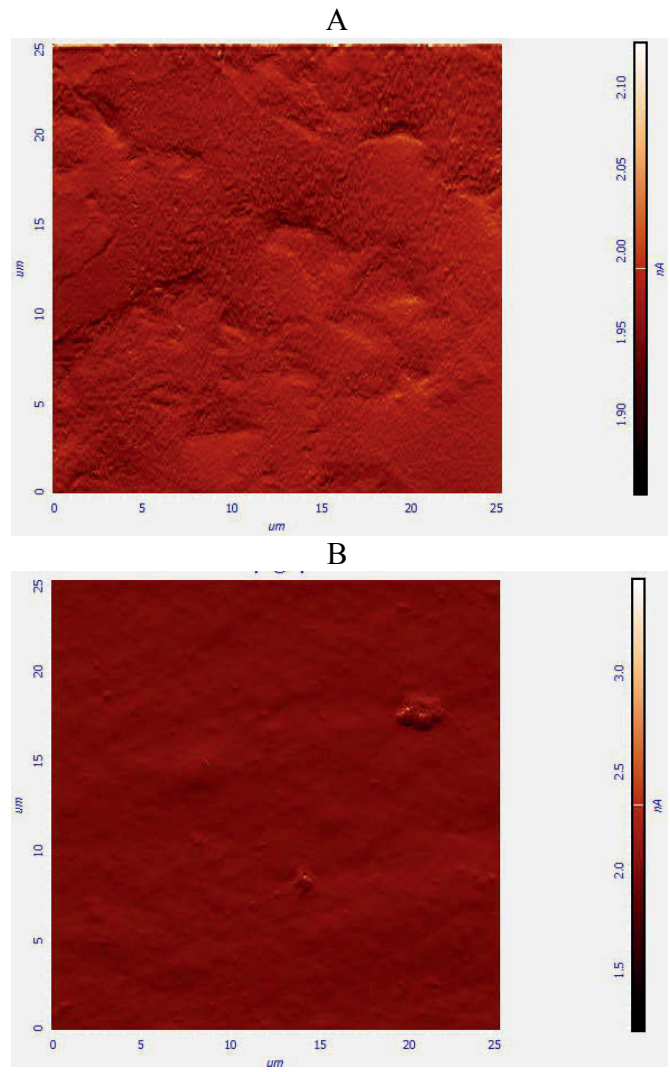

Fig. 7. Micrographs of polyethylene terephthalate. (Process gas: $33 \% \mathrm{O}_{2} / 67 \% \mathrm{He}, 15 \mathrm{~s}$ treatment $\mathrm{f}=14.05 \mathrm{MHz}$, electrode $5 \mathrm{~mm}, \mathrm{P}=55 \mathrm{~W}$,)

\section{CONCLUSIONS}

There is an urgent need for evolvement of new safe and efficient decontamination technologies at reasonable economic cost. Atmospheric pressure plasma jets might be good alternative to the traditional antimicrobial treatment and their bactericidal efficiency is already known. The main advantage of the APPJ plasma is that it can operate under the atmospheric pressure and the room temperature. Basic characteristics, results of post-reaction gas temperature measurements and concentration of ozone generated in APPJ were given.

There are still many application-oriented conditions, which should be fulfilled by APPJ devices in order to standardize the treatment process and ensure safe decontamination process.

\section{ACKNOWLEDGEMENT}

Effort sponsored by Marie Curie grant FP7-PEOPLE-PIRG05-GA-2009-249257 and 1549/7 PRUE /2010/7 MENiS grant.

\section{REFERENCES}

[1] B. Eliasson, U. Kogelschatz, IEEE Trans Plasma Sci., 19, 1063-1077 (1991)

[2] T. Montie, K. Kelly-Wintenberg, J. Roth, IEEE Trans Plasma Sci., 28, 41-50 (2000) 
[3] N. Hayashi, Y. Akiyoshi, Y. Kobayashi, K. Kanda, K. Ohshima, M. Goto, Vacuum, 88, 173-176 (2013)

[4] J. Pawłat, S. Ihara, Plasma Process. Polym., 4(7-8), 753-759 (2007)

[5] M. Moisan, J. Barbeau, J. Pelletier, N. Philip, B. Saoudi, 13th CIP, 12-18 (2001)

[6] H. Ohkawa, T. Akitsu, M. Tsuji, H. Kimura, M. Kogoma, K. Fukushima, Surface and Coatings Tech., 200(20-21), 5829-5835 (2006)

[7] J. Pawłat, S. Ihara, C. Yamabe, I. Pollo, Plasma Process. Polym., 2(3), 218-221 (2005)

[8] N. Hayashi, S. Tsutsui, T. Tomari, W. Guan, IEEE Trans. on Plasma Science, 36, 1302-1303 (2008)

[9] M. Laroussi, F. Leipold, Int. J. Mass Spectrum, 233, 81-86 (2004)

[10] H. Yu, S. Perni, J. Shi, D. Wang, M. Kong, G. Shama, Journal of Appl. Microbiology, 101, 1323-1330 (2006)

[11] J. Pawłat, Electrical Review, 10b, 139-140 (2012)

[12] G. Raniszewski, Eur. Phys. J. Appl. Phys., 61(2), 24311 (2013)

[13] N. Hayashi, T. Nakashima, A. Yonesu, IEEE Trans. on Plasma Science, 39, 2976-2977 (2011)

[14] J. Pawłat, Eur. Phys. J. Appl. Phys., 61(2), 24323 (2013)

[15] K. Kelly-Wintenberg, A. Hodge, T. Montie, L. Deleanu, D. Sherman, J. Roth, Vac. Sci. Technol. A., 17(4), 1539-1544 (1999)

[16] S. Kitazaki, N. Hayashi, IEEE Trans. on Plasma Science, 36, 1304-1305 (2008)

[17] M. Vleugels, G. Shama, X. Deng, E. Greenacre, T. Brocklehurst, M. Kong, IEEE Trans Plasma Sci., 33, 824-828 (2005)

[18] J. Pawłat, H. Stryczewska, J. Diatczyk, T. Giżewski, R. Samoń, Eur. Phys. J. Appl. Phys., 61(2), 24322 (2013)

[19] W. Guan, H. Kawasaki, T. Ohshima, Y. Yagyu, T. Shigematsu, Y. Suda, N. Hayashi, J. Plasma and Fusion Research, 8, 573-577 (2009)

[20] J. Kolb, A. Mohamed, R. Price, R. Swanson, A. Bowman, R. Chiavarini, M. Stacey, K. Schoenbach, Appl. Phys. Lett., 92, 241501 (2008)

[21] H. Stryczewska, T. Jakubowski, S. Kalisiak, T. Giżewski, J.Pawłat, JAOTs, 16(1), 52-62 (2013)

[22] Y. Yagyu, N. Hayashi, W. Guan, H. Kawasaki, J. Plasma and Fusion Research, 8, 578-581, (2009)

[23] G. Kamgang Youbi, M. Naitali, J. Herry, E. Hnatiuc, J.-L. Brisset, 12th International Conference on Optimization of Electrical and Electronic Equipment (OPTIM), Basov, 1336 - 1342 (2010)

[24] M. Naitali, G. Kamgang-Youbi, J. Herry, M. Bellon-Fontaine, J-L. Brisset, Appl. Env. Microbiol., 76, 7662-64 (2010)

[25] A. Mizuno, NATO Advanced Research Workshop Plasma for bio-decontamination, medicine and food security, Jasná, Slovakia, 17-18 (2011)

[26] A. Pierpoint, C. Hapeman, A. Torrents, Chemosphere, 50(8), 1025-1034 (2003)

[27] G. Kamgang-Youbi, J. Herry, M. Bellon-Fontaine, J-L. Brisset, A. Doubla, M. Naitali, Appl Environ. Microbiol., 73(15), 4791-4796 (2007)

[28] M. Moisan, J. Barbeau, S. Moreau, J. Pelletier, M. Tabrizian, L. Yahia, Int. J. Pharm., 226, 1-21 (2001)

[29] C. Miller, R. Valentine, M. Roehl, P. Alvarez, J.
Hazard. Mat., 158(2-3), 478-484 (2008)

[30] M. Moreau, M. Feuilloley, N. Orange, J-L. Brisset, J. Appl. Microbiol., 98, 1039-1046 (2005)

[31] Z. Machala, I. Jedlovský, L. Chládeková, B. Pongrác, D. Giertl, M. Janda, L. Šikurová, P. Polčic, Eur. Phys. J. D54, 195-204 (2009)

[32] G. Kamgang-Youbi, J. Herry, T. Meylheuc, J-L. Brisset, M. Bellon-Fontaine, A. Doubla, M. Naitali, Let. Appl. Microbiology, 48(1), 13-8 (2008)

[33] T. Maisch, T. Shimizu, G. Isbary, J. Heinlin, S. Karrer, T. Klampfl, Y. Li, G. Morfill, J. Zimmermann, Appl. and Environ. Microbiol., 78(9), doi: 10.1128/AEM.07235-11 (2012)

[34] H. Kurita, T. Nakajima, H. Yasuda, K. Takashima, A. Mizuno, J. Wilson, S. Cunningham, Appl. Phys. Let., 99(19), 191504 (2011)

[35] Z. Koval'ová, K. Tarabová, K. Hensel, Z. Machala, Eur. Phys. J. Appl. Phys., 61(2), 24306 (2013).

[36] G. Morfill, M. Kong, J. Zimmermann, New J. Phys., 11, 115011 (2009)

[37] M. Laroussi, M. Kong, G. Morfill, Plasma Medicine: Applications of Low-Temperature Gas Plasmas in Medicine and Biology, ISBN 9781107006430, Cambridge University Press (2012)

[38] M. Kong, G. Kroesen, G. Morfill, T. Nosenko, T. Shimizu, J. van Dijk, J. Zimmermann, New J. Physics, 11, 115012 (2009)

[39] K. Weltmann, T. von Woedtke, R. Brandenburg, J. Ehlbeck, Chem. Listy, 102, 1450-1451 (2008)

[40] K. Weltmann, J. Winter, M. Polak, J. Ehlbeck, T von Woedtke, Atmospheric Pressure Plasmas for Decontamination of Complex Medical Devices, in Plasma for Bio-Decontamination, Medicine and Food Security (Z. Machala et al., eds.), NATO Science for Peace and Security Series A: Chemistry and Biology, Springer, 13-14, (2012)

[41] J. Ehlbeck, U. Schnabel, M. Polak, J. Winter, T. von Woedtke, R. Brandenburg, T. von dem Hagen, K. Weltmann, J. Phys. D: Appl. Phys., 44, 013002 (2011)

[42] D. Dobrynin, G. Fridman, G. Friedman, A. Fridman, New J. Phys., 11, 1367-2630 (2009)

[43] G. Fridman, G. Friedman, A. Gutsol, A. Shekhter, V. Vasilets, A. Fridman, Plasma Process. Polym., 5, 503-533 (2008)

[44] G. Fridman, A. Brooks, M. Balasubramanian, A. Fridman, A. Gutsol, V. Vasilets, H. Ayan, G. Friedman, Plasma Process. Polym., 4, 370-375 (2007)

[45] C. Bender, L. Partecke, E. Kindel, F. Döring, J. Lademann, C. Heidecke, A. Kramer, N. Hübner, Toxicology in Vitro, 25(2), 530-537 (2011)

[46] J-L. Brisset, D. Moussa, A. Doubla, E. Hnatiuc, B. Hnatiuc, G. Kamgang-Youbi, J. Herry, M. Naitali, M. Bellon-Fontaine, Ind. Eng. Chem. Res., 47(6), 5761-5781 (2008)

[47] J. Park, I. Henins, H. Herrmann, G. Selwyn, R. Hicks, J. Appl. Phys., 89, 15-20 (2011)

[48] H. Herrmann, G. Selwyn, J. Park, I. Henins, L. Rosocha, Atmospheric Pressure Plasma Jet, Los Alamos National Laboratory, www.electrochem.org.

[49] H. Uhm, Y. Hong, Thin Solid Films, 519, 6974-6980 (2011)

[50] W. Zhu, B. Wang, H. Xi, Y. Pu, Plasma Chem. Plasma Process., 30, 381-389 (2010)

(Received April 7, 2013; Accepted September 20, 2013) 